\title{
Voices carry: An archaeology of the Hervormd approach
}

\author{
Johann Beukes \\ Department of Philosophy \\ University of Johannesburg
}

\begin{abstract}
From the investigative premise of a Foucauldian archaeology of knowledge, this article attempts to unearth the layers of ideas which constituted the Hervormd approach to doing theology over the past century. Digging into seemingly disassociated bodies of theological precedents, the article anatomizes four layers of ideas in a series of diverse orientations towards theology, namely the (1) ethical, (2) confessional and (3) dialectical orientations, and stemming from a Kantian orientation in particular, (4) the validity of 'the philosopher's voice' in the often tense relationship between theology and philosophy. Respecting the inexplicit nature of this multifarious kind of theology, the author calls for an ongoing estimation of the diversity of voices within the Hervormd approach, rejecting any attempt to integrate these different layers of thought into a monolithic enterprise of knowledge about God and the world.
\end{abstract}

\section{ARCHAEOLOGY: PROSPECTUS, RISKS \& SCOPE}

\subsection{Prospectus: Interrupting the interrupted}

"Hervormd Theology" - the approach to doing theology in the Netherdutch Reformed Church of Africa (NHKA) over the past century in particular - is somewhat of a misnomer. It should, at the very least, be stated in the plural.

\footnotetext{
${ }^{1}$ Segments of the research which made possible the publication of this article were published in Beukes (2000b, 2003). This article now pertinently employs a Foucauldian strategy in an analysis of the history of ideas as manifested in the theological labour of the Netherdutch Reformed Church of Africa over the past century. Note on translation: "Hervormd" is a unique indicator in the diverse theological and often confusing ecumenical realms of the three "traditional Afrikaans" churches: (1) the Nederduitse Gereformeerde Kerk (NGK, Dutch Reformed Church), with its daughter churches, (i) the VGK (Verenigende Gereformeerde Kerk), (ii) the NGKA (NG Kerk in Afrika) and (iii) the RCA (Reformed Church in Africa); (2) Die Gereformeerde Kerke in Suid-Afrika (GKSA, Reformed Churches in South Africa); and (3) the Nederduitsch Hervormde Kerk van Afrika (NHKA, the Netherdutch Reformed Church of Africa) and its own unique relationship with the MRCC (Maranatha Reformed Church of Christ, formerly known as the HKSA - Hervormde Kerk in Suidelike Afrika). The idiosyncratic indicator "Hervormd" supports the theological and institutional particularity and uniqueness of the NHKA within this extended Protestant community and is therefore not translated to "Reformed", thereby not contributing to the potential for confusion and misrepresentation in the English language. This is the only plausible way of distinguishing between these churches and church families in English. Where possible, the use of the applicable abbreviations is to be encouraged.
} 
"Hervormd Theology" actually consists of numerous theologies. Any investigation into the relevant history of ideas which sets out to consolidate these theologies into one, condensed and coherent orientation, one school of thought, or even one systematized idea, will run into all kinds of theoretical, procedural and methodological problems. ${ }^{2}$

I have indicated elsewhere (Beukes 1996b:233-245; 2003:31-33; 2004:884-885) what these problems are, arguing that these problems could be confronted by the implementation of the notion of "present history" in the thought of French philosopher Michel Foucault (1926-1984). The philosophical frame of reference Foucault used in the middle part of his career (1963-1971) to elucidate the notion of "present history" - how to reveal the discontinuous, fragmented, contorted ideas in history, those ideas often hidden or camouflaged by institutional power or universalizing interests, or those ideas that are merely neglected, given enough time and the natural decomposition of things gone by - is "archaeology of knowledge", a modern-critical, a-typical, historiographical methodology, which Foucault expounded in two scholarly underrated works from that middle part of his career, namely The Order of Things: An archaeology of the human sciences (Les mots et les choses [1966, tr 1970]) and The Archaeology of Knowledge (L'archéologie du savoir [1969, $\operatorname{tr} 1972])$.

From a methodological orientation of an archaeology of knowledge, I will attempt to unearth and distinguish strata of ideas which constituted the Hervormd approach over the past century. I will be digging into seemingly incoherent bodies of theological precedents, revealing four layers of ideas in a series of diverse attitudes towards theology: Ideas concerning the ethical, the confessional and the dialectical attitudes, and stemming from a Kantian orientation in particular, the validity of "the philosopher's voice" in the often tense relationship between theology and philosophy. I will attempt to explain how these discontinuous and limited theological positions co-existed for at least six decades, layered on top of each other, layered into each other, always interrupting each other, never giving in to the pressure of capitulating to the appeal for one position or layer of argument, never leading to a monolithic enterprise or "school theology" or a dominant strand of reflection on God and the world. I will show a deep respect for the inexplicit nature of this

\footnotetext{
2 "Hervormd Theology" is therefore not a useful description of the nature of theological thought in the NHKA. "Theology", in the modern sense, is generic by nature: it tends to focus on a single, exclusive and often monolithic species of theological orientation. Such a modernistic orientation compromises the plurality of discourses in the Hervormd approach. Hervormd theologians seem to prefer less generic concepts, such as "the idiomatic" (e g, Boshoff 1992:4; Koekemoer 1994:15) or even less referential and even more inclusive, "the Hervormd approach" (e g, Oberholzer [1993], Breytenbach [1999:172], Dreyer [1998:290; 1999:62-263] \& Van Aarde [1995b]). I prefer using the latter myself.
} 
multifarious kind of theology and will call for an ongoing estimation of the diversity of voices within the Hervormd approach, rejecting any future attempt to integrate these different layers into a monolithic enterprise of knowledge about God and the world.

An archaeology of knowledge, as is the case with archaeological undertakings in general, is interrupting the interrupted, said Foucault (1972:4). Digging into historical layers of ideas certainly disrupts the settled quality that time and decomposition bring to all thoughts and things. But the layers themselves interrupted the time and space they settled down in. They interrupted each other's time and space. And even more important, they hauntingly interrupt the expectations, desires and fears of the archaeologist.

Exactly for that reason an archaeology could never be an innocent enterprise. All archaeologists are grave robbers, in the sense that they consciously interrupt and disrupt that which is underground, that which went silent or was repressed ages ago - that which cannot speak for itself any longer - and yet still has a subversive, ghostly "voice" that "carries" meaning. And as any other archaeologist, I am only too aware of the interruptive nature of my layering out of that which is historically understated and underground, all too aware of the limits of my own attempt to grasp its often baffling silences and the hidden, subversive nature of its authentic contextuality. I too will be guilty of intrusion, I am not an innocent bystander. I will not only be exposing artefacts: I will move them around, I will be arranging them; I will interpret and debate the possible meaning of these artefacts. I will be argumentative. Therefore, as any other archaeologist, I will attempt to make good use of my robbery, intrusion and interruption, cautiously re-assembling the treasures of my excursion so intensely disturbed by my own subjectivity. My archaeological interpretation of the Hervormd approach is certainly not the only possible one, but it is by its immediate acknowledgement as "never innocent" a self-conscious and self-critical enterprise, and one way of dealing with and representing the history of this complex approach to doing theology.

An excavation site is never a pretty sight. Due to the relationship between power and knowledge, the layers the archaeologist encounters are forced into, over and through each other; sometimes the layers completely disappear, just to reappear yet again on another layer's level; or ín another layer; they often seem conflicting; they come to the archaeologist as essentially damaged:

Beneath the great continuities of thought ... one is now trying to detect the incidence of interruptions. Interruptions whose status and nature vary considerably ... they suspend the continuous accumulation of knowledge, interrupt its slow development, and 
force it to enter a new time ... they direct historical analysis away from the search for silent beginnings and the never-ending tracingback to the original precursors, towards the search for a new type of rationality and its various affects ... ; they show that the history of a concept is not wholly and entirely that of its progressive refinement, its continuously increasing rationality, its abstraction gradient, but that of its various fields of constitution and validity, that of its successive rules of use, that of the many theoretical contexts in which it developed and matured ...

(Foucault 1972:4)

The archaeologist will therefore never be able to lay bare neat strata of ideas, but only seemingly incoherent, criss-crossing and disrupting trails of what could only be interpreted in hindsight as layers - becoming "a discourse about discourses", as Foucault himself (1970:xix) called it. In this diversiformity the archaeologist does not find or construct anything of systemic or systematic value. The archaeologist can only acknowledge that some digging took place and some interrupted ideas were found - and again, that the digging itself interrupted the interruptive. Actually, the archaeologist will only be able to show traces of the diversity, discontinuity, thresholds and limits of the layers. Only after that acknowledgement the archaeologist can attempt to rearrange some of the artefacts he or she dug up:

The use of concepts of discontinuity, rupture, threshold, limit, series and transformation present all conventional historical analysis not only with questions of procedure, but with theoretical problems. Tracing the development and progressive refinement of ideas in any particular field is therefore extremely difficult, too difficult in fact, for conventional historiography to be of service.

(Foucault 1972:6)

“... [Archaeology] is rather an enquiry whose aim is to rediscover on what basis knowledge and theory became possible; within what space of order knowledge is constituted ... Such an enterprise is not so much a history, in the traditional meaning of the word, as an archaeology" (Foucault 1970:xxi-xxii).

\subsection{Risks: Tradition, influence, spirit}

An archaeology thus attempts to come to grips with discontinuity and the notion of the "opposing series" or the "diversiformed". But, according to Foucault (1972:6), there is a negative work to be carried out first: we must answer to the appeal of at least three notions, each of which, in its own way, uncritically fortifies the theme of continuity over time, of sustained coherence, 
a theme archaeology obviously dismisses. We have to be wary of these notions and be very sure how to approach them once we start excavating.

The first notion that requires our attention, is tradition. According to Foucault (1972:12) tradition is 1) intended to give a special temporal status to a group of phenomena that are both successive and identical (or at least similar); 2) Tradition makes it possible to rethink the dispersion of history in the form of the same; 3) Tradition allows a reduction of the difference proper to every beginning, in order to pursue without discontinuity the endless search for the origin; 4) Tradition enables us to isolate the new against a background of permanence.

Secondly there is the notion of influence, which provides an uncritical support for the facts of transmission and communication; which refers to an apparently causal process; which links, at a distance and through time, the historical and the present. The notion of influence makes it possible to group a succession of dispersed events, to link them to one and the same organizing principle.

Thirdly there is the notion of spirit, which provides ready-made syntheses, those groupings that we normally accept before any examination, those links whose validity is recognised from the outset. Instead of according them unqualified, spontaneous value, we must accept that, in the first instance, they concern only a population of dispersed events. We must also question those divisions or groupings with which we have become so familiar.

According to Foucault (1972:20), these three pre-existing forms of continuity, these syntheses that are accepted without question, are risky, even dangerous factors and must remain in suspense. They must not be rejected definitively of course, but the tranquillity with which they are accepted must be interrupted and disturbed. The archaeologist must show that these constructs are not given, or natural, but are always the result of a construction, an organization, a decision. The hallmark of an archaeology of knowledge is that it is critically aware of the risks these notions pose. But once these immediate forms of continuity are suspended, an entire field for investigation is set free. This is the field of our investigation into the Hervormd approach.

\subsection{Scope: Terrain and depth}

What then, will be the Foucauldian space of order we will encounter - and what should be the scope of our investigation? How deep should we go? How do we approximate our terrain? We should go as deep as the terrain and our equipment allow us to go. Our equipment is aporetic: the inquiry into yet hesitant analysis and interpretation of texts. Our equipment is therefore hermeneutical, which indicates its limited ability. It can neither proceed beyond the texts nor the investigative subject, it simply plays along with the game the texts themselves are playing. 
We can allow ourselves to be less hesitant when we approximate our terrain: Intellectual productivity at a facility, no, a faculty: the Faculty of Theology (Section A, for the best part of its existence), at the University of Pretoria (UP) and the surrounding area of the Faculty of Arts, as manifested over the past century. The Hervormd approach can certainly not be reduced to intellectual productivity in the 20th century, but it only became material or recognizable with the localization of early orientations in this approach within the broader event of the establishment of South African (progressively Afrikaans) university (initially "college") life in the late $19^{\text {th }}$ and early $20^{\text {th }}$ century at Stellenbosch (1866), Bloemfontein (1904) and then, Pretoria in particular. This university, initially referred to as Transvaal University College (TUC, established 1908), provided an administrative space for theological reflection in the NHKA since the second decade of the $20^{\text {th }}$ century. This important spatio-temporal consideration points toward a rather shallow excavation site, merely a century old, with its disturbed strata and layers relatively close to the surface, simplifying the scale of our archaeology considerably.

Of course, there are numerous other excavation sites: The institutional realm, the proceedings of the church, the events in the pulpit, the minutes of meetings deemed of great importance, or the social and political realm of Afrikanerdom and the enormous effect it had on the way theology was practiced and the church organized, or the socio-economic realm of doing theology in, what was for the best part of its history, a relatively small church amongst initially an oppressed, poor Afrikaner people who eventually became oppressors and agents of poverty themselves. But these are different projects altogether, and they would represent what Foucault would refer to as the move from archaeology to genealogy. ${ }^{3}$

\footnotetext{
${ }^{3}$ See for example Ernst Wolff's "Anatomie van 'n ideologiese teologie: Die Hervormde Kerk se steun aan die Apartheid ideologie" (Wolff 2006). Wolff, philosopher at the University of Pretoria, presents us with such a genealogical analysis of the way power reconfigured itself within the institutional realm of the NHKA as (initially) unrecognizable as power, exactly by analyzing minutes of meetings, church ordinances and the proceedings of documented dialogue in the church regarding racial segregation and apartheid. By investigating these institutional events within the broader scope of the changing accents in Afrikaner nationalism and power acts of exclusion within Afrikaner nationalism, Wolff concludes that the NHKA legitimised apartheid in terms of the NHKA's ideological-institutional practice. In this sense Wolf's analysis could be considered as genealogical in the Foucauldian sense. A juxtaposition of his analysis and the archaeology presented here, points towards a strange cryptogram: Namely, how has it been possible that a church which has such a mosaic, multifarious theoretical or theological self-understanding, could be so relentlessly monolithic in its institutional self-organization? I will therefore occupy myself here with the history of ideas within the NHKA and Section A at UP over the past decades - and not with the history of or changes and progress in these institutions themselves. That has already been done extensively by, amongst others, J A Loader $(1989,1990)$. See HTS 48, 1 \& 2 (1992), in its entirety, published in celebration of the $75^{\text {th }}$ year of the Section A - UP relationship.
} 


\subsection{Summary}

In our archaeology of the Hervormd approach, we expect to encounter already interrupted layers of meaning and communication. We do not expect to find neat strata of layers, equanimity and dispassionate order, but opposition, diversity, limits and discontinuity. Our strata, Foucault warned us, will be contorted and warped. That is what we have to work with. We will treat the appeal to tradition, influence and spirit, which we will undoubtedly encounter, especially so within the fascinating realm of loyalty structures in a church, with caution. We will not search for an origin, a first organizing principle, that which is authentically Hervormd. Rather, we will be on the lookout for difference and opposition. We will not be influenced by the notion of influence, and in particular not aspiring towards that one definitive organizing principle, what exactly is supposed to make a discourse or disposition Hervormd. We will be wary of the spirit of association, understating the effect a particular layer had on the church, understating our love and respect for some of our predecessors, never linking up with one single person or grouping, as if the archaeologist ever has the privilege to choose for only one layer, stratum or artefact.

\section{STRATA: ÉTHOS, STRUCTURE, DIALECTICS}

Our excavation into the history of ideas in the Hervormd approach, as manifested in theological reflection and practice at the University of Pretoria since 1908, points toward three strata of ideas, contorted, layered into each other, yet ascertainable. From the most recent - or top - layer downwards, we are able to singularize a middle and bottom layer, which are older layers, yet warped into the most recent layer, as if by some phantasmal force. The most recent of these layers points towards dialectical thinking. The middle layer points towards structural or "confessional" orientation. The oldest, deepest stratum points towards an understanding of truth as relational, that the essence or éthos of truth is to be found not in an object, but in a relation.

\section{1 Éthos: Hervormd Phantom}

The ethical stratum is not only the oldest of the orientations to be found in the Hervormd approach, but from what the layers themselves present, the most abstract. This layer prominently reveals the voice of a distinguished Old Testament scholar, James Alfred Loader (1945-), who obtained doctorates in three disciplines: Semitic Languages, Old Testament and Church History. Lecturing at the University of Pretoria (up to 1980) and the University of South Africa (up to 1997), currently Dean at the Institut für Alttestamentliche Wissenschaft und Biblische Archäologie, Evangelisch-Theologische Fakultät 
Wien, University of Vienna, this Hervormd theologian was during the past decades the most prominent agent within the Hervormd approach of what is otherwise known as "ethical theology".

Loader (1996, see 1987) refers to the ethical orientation as a historic "third option", which, in the heated theological discourse in the Netherlands during the second half of the $19^{\text {th }}$ century, provided an alternative to both the first and second options put forward in that discourse, namely "Reformed orthodoxy" and so-called "liberal theology". Loader was well prepared to engage ethically in the theological discourse of the NHKA during the last quarter of the $20^{\text {th }}$ century. One of his dissertations (Loader 1984) dealt explicitly with the appeal of the ethical orientation within the broader scope of modern European theology. He has dealt extensively with the epistemological issues the ethical orientation occupies itself with (Loader 1987:48). Loader has thus been a consistent protagonist for the argumentative revenues the ethical orientation has to offer.

Loader provides us with valuable insight into the bottom layer's reflection on God, language and truth. Obviously, éthos in this context does not refer to a moral discourse, but to the "essence" of truth, namely that truth constantly escapes the interpretation of its essence. Truth could never be encapsulated in phenomena, the analysis of phenomena or any rational projection regarding phenomena. Truth could never be objectified. Truth could therefore never be summarized, condensed or categorized by means of propositions. Doctrine which relies on propositions for its presumed truthvalue, the presumed analytical correctness or logical coherence of propositions, is doomed to failure from the outset. Truth transcends propositions, even those propositions which appeal to the transcendent itself. The proposition "God" for instance, may very well attempt to transcend the immanent by constantly redefining the proposition, but it will always be a proposition about "God" - and could never establish any sustainable knowledge about God, other than that which the proposition itself generates en regenerates.

According to the notion of truth found in the warped layers of the ethical stratum, truth is to be found in de-objectified engagement, or, is presented as subject-relational. Truth can indeed be found, or "engaged" - but it could never be explained by means of an exclusive appeal to rational constructions. A pertinent consequence of this notion of truth is that faith is being presented as an existential orientation, rather than a dogmatic conviction or a hortative, didactic enterprise. Actually, this orientation points towards an intense disinclination towards dogmatism and the obvious conviction that no concept or representation (including Biblical, dogmenhistorical and confessional 
concepts) could ever succeed in adequately representing or conveying the "truth of/about God". There is a clear preference for open-ended concepts such as the self-revelation of God, in stead of the established scholastic and early modernist notion of knowledge of God via the correct propositions, encapsulated in the correct syllogism, dogmatic structure or acceptable utterance in prayer or meditation. It is modern-critical in the sense that it is sceptical about the potential of language to reflect truth, and maintains that language would more often than not lead to dissensus - and not consensus. It is uncompromised in its willingness and eagerness to practice critical Biblical theology.

This deepest of the strata we encounter in the Hervormd approach has its own historical membrane. According to Loader (1987:50), ethical theology was transplanted into the Hervormd approach by Hervormd Biblical scholars Berend Gemser (1890-1962) and Adrianus van Selms (1906-1984). Both expanded themes initially established by late $19^{\text {th }}$ century Dutch theologians Daniël Chantepie de la Saussaye (1818-1874) and Johannes Hermanus Gunning jr (1829-1905). Ethical theology, as mentioned, was in its initial guise an "orientation" or "course" in the bitter theological debate in the Netherlands in the second part of the $19^{\text {th }}$ century, between what was called in that particular context "liberal theology" and "Reformed orthodox" theology. Ethical theology now provided a third option, a way out of the gridlock created by the ferocity of both adversaries in that debate. Theologians such as De la Saussaye and Gunning jr engaged actively in the debate, without conforming to the discursive headlines and deadlines laid down by those two polarizing corners. According to Loader, ethical theology started to operate somewhat incognito in the aftermath of the debate, although it certainly created a new theological presence or realm for theological orientation in Western Europe and beyond.

This deepest layer at our excavation site reveals other names as well, in particular J H J A Greyvenstein (see Van Eck 1999:41-42) and E S Mulder (see Breytenbach 1992:108), as well as their intellectual stipendiaries in Biblical scholarship, A P B (Andries) Breytenbach (e g Breytenbach 1999:173) and $\mathrm{E}$ (Ernest) van Eck (e g Van Eck 2006:692-695), both evidently embedded in the epistemology of ethical theology. But we certainly do not encounter a historical-discursive layer packed with artefacts, protagonists and references. Had we engage in a conventional (modern) historiography of the Hervormd approach, this lack of copious artefacts and references might have seemed like a deficiency. We would have been looking for a beacon of thought, for formalized influence, for repetition, for continuity, for an idea that became a school of thought. This deepest stratum does not provide us with these notions. But for the archaeologist this meagerness has to be the beauty 
of the ethical presence in the Hervormd approach. Although it never established itself as a school of thought in the Hervormd approach, it created an open discursive sphere which over many decades drummed into the Hervormd orientation about knowledge of God and the world. Even though few Hervormd theologians would openly refer to themselves as "ethical", the above-mentioned notions on truth and language run as cross strata through the Hervormd history of ideas up to the present. The ethical orientation is absent, yet spookily present in the Hervormd approach.

The eerie presence of the ethical orientation is, for instance, clearly detectable in the work, church guidance and proceedings of the $67^{\text {th }}$ General Commission (2004-2007) of the NHKA, especially so in the published addresses, sermons and articles of its chairperson, Johan Buitendag, Professor in Dogmatics and Christian Ethics at the Faculty of Theology at UP and Moderator of the NHKA (2004-2007). In two published articles (Buitendag $2006 a \& 2006 b)$ the always-recurring backwash of the ethical orientation is clearly detectable: Even a casual listing of remarks in the most recent of his publications, clearly indicates that whether Buitendag deals with confession and contextualization, ${ }^{4}$ church and identity, ${ }^{5}$ or ecumenism, ${ }^{6}$ the ethical

\footnotetext{
4 "The first Christians were thus already confronted with the challenge to contextualize the essence of the Gospel in their own situation ... It is crucial to understand that a root confession simultaneously throws itself back and forward in a new situation, simultaneously re-vealing and re-veiling the mystery of God, simultaneously consoling and exhorting ... we conclude that the legacy of Jesus was interpreted anew in every new and different circumstance" (Buitendag 2006a:344, my translation). "[When engaging in theological hermeneutics] .... only proportional analogies are really possible .... There is always a surplus of meanings which simply cannot be formulated. That is why we proclaim that God Himself, even in His revelation, is hidden. We know and understand God only partially. This conviction points toward a reserved, modest enterprise and confirms our dependence on God" (Buitendag 2006a:346, my translation).

5 "The church should resemble liquid, water - flowing and moving ... the church is far more than the gathering of the righteous on a certain place at a certain time ... rather, the church is a flowing, communicative network of relations", (Buitendag 2006a:344, my translation). "Church is an event and therefore a dynamic community that constantly takes shape in terms of language and culture", (Buitendag 2006b:799). "Kairos, the crucial moment, as any moment of truth, could never be manipulated nor simulated", (Buitendag 2006a:353, my translation). "The NHKA understands itself as a confessing (and not a confessional) church. Truth could never be encapsulated in a teaching, dogma or a religious conviction. Truth is in the first instance a Person, Jesus Christ, and this truth transcends every mundane attempt to the formulation and formalization of the truth. Confession should be the consequence of an engagement with the living God", (Buitendag 2006a:357;361, my translation). "Truth is not to be seen only as clinical and unattached in the sense of the Vincentian canon. The NHKA in particular believes that truth is much more than and often even quite different from neatly formulated propositions ... we are modest, acknowledging that we can understand only partly" (Buitendag 2006b:791).

6 "Dialogue does not produce truth; dialogue discovers the truth that is given to us once and for all in Jesus Christ ...", (Buitendag 2006b:797). "We are of the opinion that truth can not be utterly grasped in a doctrine. Truth is primarily a Person and essentially transcends all concepts and propositions. It is no rational comprehension of the current reality, but an encounter with the living God" (Buitendag 2006b:801).
} 
orientation strikes one as being so part of his epistemological make-up, that he does not seem to ever find it necessary to expand on its resources. To Buitendag, thinking ethically simply is a sine qua non for Hervormd reflection. This epistemology comes natural to him. Next to Loader, Buitendag is the most visible - since we stay clear of the notion of influence - contemporary example of the way the ethical orientation eerily crawls back into the Hervormd approach; eerily, exactly because there is no obvious reason for it. The ethical orientation does not constitute a school of thought, has never been formalized or systematized and has never been a firm ideological premise for doing theology in the Hervormd fellowship. And yet it is so warped and layered into the other layers we will encounter, that the Hervormd approach would be unrecognizable in its absence.

\subsection{Structure: Say now Shibboleth}

The middle layer we encounter in our excavation is much more dense, packed with discursive artefacts. It is less subversive, almost straightforward in its formalized self-presentation, not as phantom-like as the bottom layer in the way it carries its voice forward in the Hervormd approach. The middle layer presents us with an evident respect for structure, arrangement, hierarchy and organization. It reveals a reliance on structural considerations such as language-systems, the organization of concepts, accountability in the face of history and, in particular, the phenomenon that connect these three structural considerations in one tight cuff: The claim to truth via confessional systems.

It is clear from the outset that a wide array of Hervormd contributors, voices and legacies are amalgamated on this level. The layer presents us with so many contributors to the design of its density, that it becomes very difficult to opt for or isolate one voice which could possibly emblematize the aura of its theological appeal. But in terms of polemic accomplishment and remonstrative vigor, two names seem to be pushed forward by the others: J P (Bart) Oberholzer, Dean and Professor of Old Testament at Section A and moderator of the NHKA during the 1970s and 1980s, and D J C (Daan) van Wyk (sr), Moderator of the NHKA during the early and middle 1990s. In critical response to Loader's aforementioned exposition of ethical epistemology, Van Wyk utilizes his critique of the ethical orientation to expand on what the core distinctions of the "confessional orientation", seemingly the preferred selfidentification on this level, are (see Van Wyk 1998:250-260; 1999a:121-122; 1999b:191). By employing the thought and legacy of Dutch "confessional" theologian, P J Hoedemaker, lecturer in theology at the Free University of Amsterdam in the last quarter of the $19^{\text {th }}$ century, Van Wyk points out that the confessional orientation always had the well-being of the church in mind. It is primarily theology in service of the church - and not the university. Yet one 
would not be able to isolate this orientation from the open-ended discourse facilitated by the critical dimensions of university life. In Hervormd guise the confessional orientation therefore does not understand itself to be fundamentalist in approach or uncritical towards the systems of language and knowledge it relies so heavily upon. It claims that it is aware of their restrictions. It does not, in other words, understand itself to be confessionalist - but rather confessionally orientated (Van Wyk 1998:248; 1990:510-511). In that sense it could not be regarded as confessional in the coercive sense the scholastic Gereformeerd version of truth being confessionally "wrapped" would have it (Pont 1994:105). It is, indeed, "thoroughly confessional" - "deur en deur konfessioneel" (Pont 1994:106), but it is in its own opinion self-critical and it does resist epistemological fundamentalism.

In two nuanced and illuminative articles by Oberholzer (1993:881; 1994:33-34; echoed by his successor as Dean of Section A, J H (Johan) Koekemoer [1994:19]), our middle layer is depicted as a liberating and not a restrictive kind of confessional orientation. It is a confessional direction often not distinguishable from the epistemological premises of the ethical orientation - it seems the old phantom truly warped itself into the heart of confessional orientation within the Hervormd fellowship. The confessional orientation is nevertheless unmistakably a species of confessional theology - and while Hervormd theologians would always consider themselves to be confessional, at least to an extent, some are steadfast about not being "confessional theologians". 7 Oberholzer in particular, often decidedly embraces the tense, questioning notion of truth presented by the ethical orientation and he can indeed be very critical of the confessional orientation, so much so that one hesitates to depict him as an exponent of the confessional orientation. Yet his legacy is to be found in the folds of the middle layer. That is the appeal of the Hervormd version of the confessional position and a theologian such as Oberholzer: The shadowy presence of the ethical orientation yet again crept into this self-understanding, reappearing on this level, giving it an uneasy demeanor. This confessional orientation is simply not of the same kind as one would encounter in Reformed orthodoxy or Gereformeerd theology proper. Oberholzer's queasy position within the confessional orientation is a good example of the reality that Hervormd and Gereformeerd are two completely different phenomena.

\footnotetext{
${ }^{7}$ The dominant figure in contemporary Hervormd intellectual labour, New Testament scholar A G van Aarde, whose legacy is to be found at the top layer (we will arrive there shortly), wrote a compelling article on, amongst other things, why he could never be a "confessional theologian", although he certainly considers himself to be "confessional" (Van Aarde 1995a\&b; esp 1995b:58[7]). I have used the same demarcation to stress the opposite side of the argument: "... it would be reckless to compare Hervormd confessional orientation to confessionalism and simply wrong to call it orthodoxy ..." (Beukes 2003:35).
} 
The peculiar Hervormd version of confessional orientation confessional, yet not confessionalist; free, yet within bounds ("... vry, maar nie bandeloos nie ...", Oberholzer 1993:874), has been labeled "BiblicalReformed theology" - Bybels-Reformatoriese teologie - by a number of conservative theologians in the NHKA during the 1960s in particular. Although the "Biblical-Reformed" orientation was already - as a self-depiction - in use in the 1940s in the NHKA, it was only during the 1960s that the concept was employed, properly and polemically, distancing itself from what was considered to be wayward, even reckless trends in the Biblical sciences. By employing this mode of self-understanding, some exponents of the middlelayer discourse in the NHKA stressed their commitment to Biblical theology taking the canonized texts, the structured confessions and the systematized dogmenhistorical documents seriously, developing a critique of church and world on that basis and revealing an acute sense of embeddedness in tradition, yet a willingness to engage in discourse about history and accountability (see Oberholzer 1993:880; Van Zyl 1999a:24-25). Unfortunately it is true that one does encounter exponents of BiblicalReformed theology who do not seem to respect the restless nature of the Hervormd approach, even in its Hervormd confessional modus. There still are theologians within the NHKA who strike one as being quite content with confessional systems as such: Not only would they uphold the notion that these systems fundamentally (not merely adequately, not to speak of relatively) proclaim the truth about God - they would go as far as accuse those who differ from them or their interpretation of the vital texts - the Bible and/or the confessional scripts - of heresy. There were a few of these unfortunate events in the past decades, one of them ending in litigation and findings of the High Court in a delict proceeding (the notorious Geyser case of the 1960s - for an outstanding analysis, see Krüger 2003:461-468), the confessional controversy ("belydenisstryd") of the mid-1990s and the controversy surrounding postmodern philosophy in the mid- and late $1990 \mathrm{~s}^{8}$ These controversies, without exception initiated by the cadres of BibilicalReformed theology, did not contribute to a deeper understanding of the Hervormd approach. These controversies undermined the delicate, polivalent nature of this approach and isolated Biblical-Reformed theology from its roots in the Hervormd version of the confessional orientation. In his otherwise solid analysis of the Hervormd approach, Gereformeerd theologian $\mathrm{J} \mathrm{H}$ van Wyk

\footnotetext{
${ }^{8}$ I have put forward a philosophical analysis of these and other controversies within the Hervormd fellowship over the past four decades, concluding that these events were harmful not only to the NHKA, but to the multifarious nature of its theological orientation (Beukes 2000c: 54-56, 60-67; see 2003:35[10]).
} 
(2000:475) is therefore tempted to present Biblical-Reformed theology as a separate orientation within the Hervormd approach. A thorough investigation of the discursive artefacts on the middle layer does not support such a conclusion: rather, Biblical-Reformed theology is a polemic strand within the confessional orientation. Exactly because of its polemic nature, the BiblicalReformed strand is very exclusive, very generic and very reductive, predisposed towards hermeneutical bias and not capable of engaging in the tense theological discourse its Hervormd-confessional source is renowned for.

One would have to agree with the implication of Oberholzer's analysis of the legacy of $\mathrm{B} J(B e n)$ Engelbrecht, a contemporary of his and systematic theologian at Section A in the 1950-1970s, evidently a prominent exponent of Biblical-Reformed theology, that the inherent critical capability BiblicalReformed theology is supposed to have inherited from its Hervormdconfessional source, the philosophical potential Engelbrecht showed in his exciting Kierkegaard-Hegel-Barth dissertation (e g Engelbrecht 1949:49), as well as the explosive kind of dialectical thinking the younger Engelbrecht certainly was capable of (Beukes 2000:6-8), never properly manifested in the theological discourse in the NHKA. Rather, one is obliged to refer to the way Biblical-Reformed theology has indeed manifested in the NHKA, of which Engelbrecht's legacy is exemplary, as "conservatist" and "dogmatist" (Oberholzer 1993:880-883), or even as "uniquely neo-Calvinist" (Beukes 2000c:8) - not a complement of its Hervormd-confessional source, which would never strike one as conservatist or dogmatist and certainly not as neoCalvinist. If "Hervormd Theology" is not a useful apprehension of the nature of theological thought in the NHKA, "Biblical-Reformed theology" is even less so. ${ }^{9}$ It is simply too generic and reductionist; suppressing the one precious element to be found in all layers of the Hervormd approach: An epistemological inclination towards the acknowledgement of the imperfect, fallible nature of theology (Beukes 2000a:245-248; 2000c:65-72; 2004:883885). Biblical-Reformed theology could, in the end, be understood as a polemic if not apologetic tactic during the turmoiled 1960s intended to distance the NHKA from liberal theology, on the one hand, and on the other hand, to streamline the NHKA within the loyalist nature of apartheid politics with the Gereformeerd theologies of its two Calvinist sister-churches, the NGK and GKSA, providing the apartheid state with an uninterrupted reinforcement of religious - specifically Calvinist - solidarity it so acutely required for moral,

\footnotetext{
${ }^{9}$ It is significant that Unisa philosopher of religion J S Krüger, in an informed, serene analysis of the Hervormd approach, as part of a larger celebrated Religionswissenschaftlice work, not even once in that analysis refers to "Biblical-Reformed theology" (Krüger 2003:422-427).
} 
civil and economic self-preservation. ${ }^{10}$ Our excavation of the layers of the Hervormd approach does not affirm the notion of Biblical-Reformed theology as a core orientation or independent layer in the Hervormd approach - and does not find wide appreciation for that notion.

What our excavation does confirm, is that the Hervormd version of the confessional orientation is the least contorted and least warped of all the layers; it seems, therefore, to be more stable and stabilizing than the other layers, possibly seducing contemporary recipients of this orientation to believe it to be of cathartic or even purgative value. But our archaeology, extremely cautious of notions of continuity, in its furthering of the deciphering of artefacts on the middle layer, indicates otherwise: The main reason the confessional orientation seems to be so stable is to be found in its ability to repel destabilizing angles. This buttress of stability in the Hervormd approach actually only resembles stability. Beyond its stable façade is the deceptive bulwark of continuity. The confessional orientation not only trusts continuity, it relies on the notion of continuity to fortify itself, making itself intellectually invulnerable, making its claims about God and the world unassailable. The confessional orientation works exclusively with principles of identity, which in turn confirm the truths initially generated and eventually guaranteed by the continuity these principles made possible in the first place.

This is a tough circle to break in or break out of; identity and continuity enjoy complete reciprocity and immunity in this regard; they fiercely defend and immunize each other. The identity politics of the confessional orientation starts with the notion of the Godhead as an entity that is to be formulated, correctly, according to a system of principles that enjoy some correspondence "in the world", making them "principles of identity". Taking the often syllogical nature of these principles further, fully expanding them into the social realm, is an event its exponents would consider logical and natural. Typical principles of theological identity, such as a) the confessional scripts of a large number of Protestant churches (specifically The Netherlands Confession of Faith, The Heidelberg Catechism and The Canons of Dordt), b) church laws, statutes, orders and ordinances as well as c) an established if not canonized interpretation and reception of local and colonial-European history, provide the confessional orientation with fixed, unwavering criteria by means of which a continuous appeal could be made to an external, fixed or "objective" reality, a

\footnotetext{
${ }^{10}$ For an informed analysis of and elaboration on this point, see Krüger (2003:358-381); for a credible and nuanced exposition on the historical background of political orientations within the NHKA over the past decades, see Wolff (2006:143; 2000:1202); compare the delicate analysis of I W C van Wyk (1994a-b, 1997) and the clear trajectories concerning racism within the NHKA Van Staden (1994) isolated.
} 
reality that could be transferred unhindered from one historical context to another.

But even more crucial is that these criteria can be utilized to establish norms for the acceptance - or rejection - of ideas and practices: Whether a contemporary idea or practice conforms to the established, already existing system of knowledge, tradition, ecclesiastical convention, and so on. Along these lines principles of identity create a fixed space for the continuous externalization of social reality as well as the continuous internalization of identity. The confessional orientation seems stable only because the social reality it engages is always already externalized, could therefore always be transferred unhindered to a next and new context; it seems stable only because it continually enables itself to sanction identity and veto practice, which subject, subjective idea or subjective act still conforms to the internalized norm, who "we really are".

The externalization of social reality and the internalization of identity has only one dynamic at its disposal - exclusivity. Its success is measured according to the dynamics of Say Now Shibboleth, ${ }^{11}$ the establishing of what is inside and what is outside. The unknown must either conform to the parameters of what is known - or it must be discarded. Whether it is an idea about God, incarnation, resurrection, virginal conception and what else - the boundaries are always already set, the convictions are always already established. In its reflection about God and its focused formulation of propositions about God, principles of identity attempt to find something universal or general between the known and the unknown that could logically tie it to the known - so that whatever does not conform to the restrictive logic of its self-defined knowability, could be fended off as not worth knowing, as folly, or, at its worst, as a subversion of truth, beauty and justice. That is why the confessional orientation would always opt for dogma before discourse, programme before poetry, verification before speculation, principle before virtue: discourse, poetry, speculation and virtue make things somewhat unsafe and very unstable.

\footnotetext{
${ }^{11}$ A shibboleth is a linguistic password: A way of speaking that identifies one as a member of an in-group. The purpose of a shibboleth is exclusionary: A person whose way of speaking violates a shibboleth is identified as an outsider and thereby excluded by the group. The word shibboleth in ancient Hebrew dialects meant "ear of grain" (or, perhaps, "stream"). Some groups pronounced it with a sh sound, but speakers of related dialects pronounced it with an $s$. The word has an interesting background: Two Semitic tribes, the Ephraimites and the Gileadites, had a great battle. The Gileadites defeated the Ephraimites and set up a blockade to catch the fleeing Ephraimites. The sentries asked each person to say the word shibboleth. The Ephraimites, who had no sh sound in their language, pronounced the word with an $s$ and were thereby unmasked as the enemy and slaughtered (Judges 12:1-15 [6]).
} 
That is why, in the confessional orientation, the confessional scripts of the church are deemed so important and that is why the precise wording and precise formulation of confessions and conventions are so crucial, why language should be trusted, why Shibboleth should be said. These scripts erected highly sophisticated systems of knowledge which attempt to resolve the asymmetric in terms of the symmetric, to resolve hostile contingency in terms of kindred certainty. Its effectiveness is measured according to its ability to convey its certainty, the total continuity of its foundational inquiry, into "theologies", which are far more expansive systems of knowledge, in the sense that they touch on every aspect of individual and social life - they go far beyond the initial attempt to say something coherent about God. The words and the propositions are the conveyors of the stable systems theologies need to be, if they want to transplant contexts credibly: Words provide an otherwise fragmented socio-historical process with a sense of sameness and uninterrupted continuity.

Even in self-aware Hervormd guise, the confessional orientation leaves the strong impression that it trusts the sense of sameness and continuity. It finds refuge in the continuum, even to the point where the means by which the continuity was made possible in the first place, progressively refined by tradition and transfer, are being fully ignored. The confessional scripts of the church, for example, are being interpreted and appreciated as documents of continuity, whilst they are without exception documents of negativity, texts which demonstrated against continuities in their own particular contexts. These texts are essentially negating - yet they are appreciated as confirmations of order, as documents of continuity. God is being presented as a highly organizable, systematizable and certainly as an identified entity while the presentation is simply an attempt to grasp something which does not organize itself, to put it mildly, according to human disposition. God is being presented in organic terms as an all-representative unit. The confessional orientation leaves the strong impression, in its own particular jargon, that reflection on God must be equally organic, equally organized, as constant, eternal and enduring as God in reflected, constructed, interpreted Being is deemed to be; eventually, it aspires more to theos than to logos, refuting hermeneutics to a large extent.

For example: The Belgic (or Netherlands) Confession of Faith, sets out in its first article to say something it considers to be coherent about God: "We all believe with the heart, and confess with the mouth, that there is one only simple and spiritual Being, which we call God; and that $\mathrm{He}$ is eternal, incomprehensible, invisible, immutable, infinite, almighty, perfectly wise, just, good, and the overflowing fountain of all good", (my italics). These are all too familiar concepts, Aristotelic-scholastic in origin. Obviously there is a particular 
socio-historical backdrop against which this proclamation should be understood. But the problem establishes itself exactly in the organic, universalizing movement beyond the particularity of that proclamation, again, in the externalization of social reality as well as in the continuous internalization of identity. Perhaps, from an archaeological point of view, the most valuable word in that first article is the word call - because it seems that word's authenticity was the first to be lost in transfer. We can call God whatever we want - but for the rest, it is up to God to be God.

The confessional orientation provides a sense of stability in the Hervormd approach, but from an archaeological point of view, it is a false sense of stability. The confessional orientation confides in an attachment, a ready-made synthesis, between identity and continuity. An archaeology of knowledge unmasks this comfortable synthesis, because it grasps that layers, links and intersections are broken and damaged. Archaeology proclaims discontinuity, deeply embedded in the conviction that all discourses are interrupted, damaged socio-historical phenomena - and that theology is at its vainest when it refuses to recognize its own broken discursiveness, its own fragile layeredness in history. No structure, no password, no proposition and no confession can save the confessional orientation nor confessional theology from this archaeological reality which its dusky tombs reveal: Mensewerk, alles mensewerk (Labour, all of it).

\subsection{Dialectics: Yes, it is about the No}

Whereas the middle layer seems to be the less contorted and warped of the layers we encounter in our archaeology of the Hervormd approach - for reasons stated above - the most recent of these layers seems to be far more contorted and skewed than the others. Actually, this layer reflects by its very nature tension and interruption to a far greater extent than even the deepest of the layers, that old Hervormd shadow, the ethical orientation. ${ }^{12}$ On this layer, for the first time, we encounter the disturbing voice of the philosopher, the Schleiermacherian, the existentialist, the postmodern hermeneutician and the philosopher, as we will see, is ironically responsible for the warpness, for the tense ability to utter the words yes and no in the same sentence. Ironically, because nowhere else the position of the philosopher would be more strained in theology than within the dialectical orientation. Yet nowhere else is it more clear that the Hervormd approach was and still is more

\footnotetext{
${ }^{12}$ Obviously, given their contorted and in-laid nature, this does not mean that fascinating parallels and homologues between the ethical orientation and dialectical theology could not be pointed out. One theologian in particular represents the source of these parallels in the history of ideas in the NHKA - Th L Haitjema, who enjoys a legacy on both levels and seems to be very much appreciated in the Hervormd fellowship on all three layers laid bare. The name of $G \mathrm{C}$ van Niftrik also features prominently in this regard, although both Haitjema and Van Niftrik would be considered conservative if not antiquated by younger Hervormd theologians: Leading us into the deeper labyrinths of dogma, however eloquent, is leading us nowhere.
} 
philosophically guided than any of the other theologies of the churches in the extended Protestant community the NHKA finds itself in (compare Krüger 2003:423). However shallow or recent this layer may be, some of the voices that carry its legacy forward, are fully established in the Hervormd fellowship: The voices of Emil Brunner ${ }^{13}$ and Karl Barth, ${ }^{14}$ in particular. Had our

\begin{abstract}
${ }^{13}$ Emil Brunner (1889-1966), the Swiss Protestant theologian who had such a tremendous impact on early dialectical theology in the NHKA, was a principal contributor to what came to be known popularly (though unfairly so) as "neo-orthodoxy", which was, like the ethical tradition, in opposition to late $19^{\text {th }}$ and early 20th century liberal theology. Brunner rejected liberal theology's portrait of Jesus Christ as merely a highly-respected human being. Instead, Brunner insisted that Jesus was God incarnate and central to salvation. Brunner also attempted to find a middle position within the ongoing Calvinist debate, stating that Christ stood between God's sovereign approach to humankind and our free acceptance of God's gift of salvation. Although Brunner re-emphasized the centrality of Christ, conservative theologians have often been hesitant to accept Brunner's other teachings, including his rejection of certain "miraculous" elements of the Scriptures and his questioning of the usefulness of the doctrine of the inspiration of Scripture. Like Karl Barth, he challenged the leaders of modern rationalist and liberal theology, and proclaimed a theology of revelation. The Christian faith, he maintained in almost ethical fashion, arises from the "encounter" between individuals and God as He is revealed in the Bible. Brunner, in attempting to leave a place for "natural theology" in his system, came into conflict with Barth exactly over the question of natural revelation. Brunner refused to accept the radical divorce between grace and human consciousness that Barth proposed. Brunner and Barth had a tendentious and rocky relationship, differing sometimes dramatically over their theological views. For a broader discussion of Brunner's influence on the Hervormd approach, see Beukes (2000c:142-150).
\end{abstract}

${ }^{14}$ Karl Barth (1886-1968) was originally trained in German Protestant liberalism, but reacted against this theology at the time of WWI. His reaction was informed by several factors, including his commitment to the German and Swiss Religious Socialist movement, the influence of Biblical Realism, and last but not least, the then newly discovered proto-existentialist philosophy of Danish philosopher, Aabye Søren Kierkegaard. The most important catalyst was, however, his reaction to the support some of his liberal teachers had for German (WWI) war aims. Barth believed that his teachers had been misled by a theology which tied God too closely to the finest, deepest expressions and experiences of cultured human beings, into claiming divine support for a war which they believed was waged in support of exactly that refined culture of Bildung. In 1919 his explosive Commentary on the Epistle to the Romans or Römerbrief catapulted Barth into international theological prominence. In his Römerbrief Barth famously stressed the "infinite qualitative difference" between God and man, which is a central Barthian concept. According to the Bible's own testimony, says Barth, revelation is entirely the gracious selfdisclosure of the utterly transcendent and otherwise hidden God in the person of Jesus Christ. This revelation is the "crisis" or judgement of all human activities, including religion. In this work Barth strongly opposed liberal theology's blurring of the divine-human distinction and the subordination of Christian faith and ethics to the passing standard of each historical period. Barth's theological "revolution" thus was a dynamic, non-fundamentalistic recovery of the Biblical message as the proclamation of the unique self-disclosure of God to humanity in Jesus Christ. He believed that theology ought always to derive its entire thinking on God, humanity, sin, ethics, and society from what can actually be seen in Christ, as witnessed by the Old and New Testaments, rather than from sources independent of this revelation. His writings explore the implications of this total Christ-centeredness. Barth had a tense relationship with philosophy, the consequences of which will soon be discussed. From Barth's perspective, liberal theology, as understood in the sense of 19th century thought with Friedrich Schleiermacher and GFW Hegel as its leading exponents, is to Barth a "divinization" of human thinking. This inevitably leads one or more philosophical concepts to become for Barth the "false God", thus blocking the "true voice of the living God". These divinized concepts lead to the captivity or subordination of theology by philosophy. In Barth's theology, he emphasizes that human concepts of any kind, however philosophically delicate and nuanced, can never be considered as identical to God's revelation. In this respect, Scripture, also written human language, is expressing human concepts. It cannot be considered per se as identical to God's revelation: the Bible merely points toward the revelation. However, God reveals Himself through human language and concepts, with a view toward their necessity in reaching fallen humanity. Thus Barth claims that Christ is truly presented in Scripture and the preaching of the church. The bottom line is: Barth stands in the heritage of Calvinism in his accent on revelation "alone" and his consequent objection to any attempt to relate theology and philosophy too intimately. His approach in this respect is termed "kerygmatic" as opposed to the Brunnerian "apologetic" approach: Brunner's position emphasized an extremely intimate relationship and interaction between philosophy and theology, although his position does not boil down to the complete lack of differentiation between the two, as is the case with, for example, Tillich. 
archaeology allowed us to isolate a single, typifying strand of thought or school orientation within the Hervormd approach, this probably would be it: Dialectical theology, Barth and Brunner, keeping their differences in mind, with, in its contemporary guise, the modern-critical (or negative) kind of philosophical dialectics, philosophical hermeneutics and critical realism that underlie it.

According to Pont (1994:107; see Krüger 2003:422), the dialectical orientation has exerted a strong influence on the Hervormd approach since the appointment of systematic theologian and philosopher of religion $\mathrm{H} \mathrm{P}$ Wolmarans (1894-1980) as professor of Religion and Mission at Section A in 1935. Wolmarans interpreted Brunner in particular for the NHKA in a period of great uncertainty and strife, in the aftermath of the depression and extreme poverty amongst the Afrikaner people in the early 1930s, up to the immediate aftermath of World War II. On the dialectical layer, the voice of Brunner is settled much more deeply than that of Barth in the NHKA (for an expansion, see Beukes 2000c:8-15). It should come as no surprise that more recent attempts from a younger generation of philosopher-theologians in the NHKA would go directly back to and link up with the critical apologetics of Brunner, and not the sealed and shut, essentially Hegelian dialectics of Barth. ${ }^{15}$ Given the (sadly unrealized) philosophical potential of B J Engelbrecht's previously mentioned dissertation, which was from a Kierkegaardian perspective often vehemently critical of Barth, and given the negative impression some Hervormd theologians, in a church context renowned for its political and social conservatism, might have had about Barth's outspoken social and political liberalism, one would expect the reception of Barth to encounter some problems within the Hervormd approach. Either someone with extraordinary theological skill and rhetorical capability would have had to step in to salvage Barth for the Hervormd discourse - or Barth simply had to be assimilated to existing Calvinist - or "Biblical-Reformed" - thought. Both happened:

Engelbrecht in particular packaged Barth in a conservative format, fitting the requirements of a resistance against a socio-cultural reception of Barth (see Krüger 2003:425). Yet a not so "right-Barthian" (Krüger's term, 2003:425), but rather an "intellectualized-Barthian" (my term) reception, did gain momentum in the NHKA, via the focused and productive religious-philosophical labour of Wolmarans' successor, F J (Frans) van Zyl (1913-), appointed at Section A in

\footnotetext{
${ }^{15}$ I have given a more detailed explanation of this rehabilitation and have myself sought refuge in Brunner's apologetics in an aporetic attempt to incorporate the negative dialectics of Frankfurt School philosopher Theodor W Adorno in the dialectical orientation in the NHKA (Beukes 2000c:131-136,140-149). The "apologetic" character of Brunner's sense of dialectical theology allows such a philosophical intervention, expansion or improvisation, while Barth's rather unique positivism (see the last paragraph of footnote 14) would make such a turn impossible.
} 
1961. Only since the early 1960 s these two receptions of the Barthian version of dialectic thought really caught on in the NHKA and were established as fundamental to its theological positioning. It was only then that Barth's theology became integrated with and eventually surpassed the legacy Brunner himself already enjoyed for close to three decades in the Hervormd approach.

No one has done more to establish Barth in the Hervormd approach than did Van Zyl, possibly amongst the top yet internationally underrated Barth scholars of his day. Since the publication of his celebrated dissertation, "Die Analogia Entis: 'n Godsdiensfilosofiese Ondersoek" (1958), under what was a problematic supervision by the Brunnerian H P Wolmarans, an intellectualized Barth was quickly and firmly established in the Hervormd approach. Very few Hervormd theologians, even those inclined to the ethical and confessional orientations, would dispute the lingering effect Van Zyl's interpretation of Barth did have on the Hervormd approach, even on the Hervormd "way of life" (see Die Hervormer 1 October 1993:4; Breytenbach 1999:175; Van Wyk 1999b:193; compare Van Zyl 1958:61). ${ }^{16}$

Yet Van Zyl does not present us with much innovative dialectical theology. He was an outstanding disciple of Barth and certainly understood the intricacies in Barth's dialectics very well. He employed Barth's theology with remarkable success in a context very distant from Western Europe and the post-WWII theological discourse in Europe. But over a course of nearly five decades one would not find a single instance where the disciple stood up to his master. In all his publications - and there are many of them - Van Zyl never gave any proper indication of either a critique of or a firm disposition against Barth. Even if a Brunnerian would have a somewhat opportunistic expectation of a dramatic confrontation between the "right-Barthian" reception of Engelbrecht and his partners in their Calvinist "Biblical-Reformed" orientation and the "intellectualized-Barthian" reception of Van Zyl and a fellowship of upcoming and bright systematic theologians in the NHKA, $\mathrm{J} \mathrm{H}$ Koekemoer, G C Velthuysen as well as the much younger I W C van Wyk and J Buitendag in particular, it simply never happened. Barth was evidently

\footnotetext{
${ }^{16}$ I have held Van Zyl responsible (Beukes 2000c:144) for an exclusive Barthianism at the cost of an ongoing and balanced reception of Brunner and, at the very roots of dialectical theology, at the cost of Schleiermacher and the early hermeneuticians, often in absurd caricatures of the hermeneutical tradition that beyond any doubt nourished the Hervormd approach. In a discussion between the author and Van Zyl on July 30 2006, the elegant old master, in a rare moment of self-disclosure, acknowledged that he indulged in the overstatement of Barth in dialectical reflection in the NHKA, to the cost of "other important, yet lesser ones" - One would have to say Brunner, in particular. Yet, a true fixating disciple, Van Zyl is not satisfied with even this overstressed reception and considers Barth to be still underrated if not widely misunderstood in the NHKA.
} 
deemed too precious to be compromised by in-fighting. The absence of such a confrontation, as well as the fact that neither reception of Barth ever came close to upsetting a theology of racial separation in the NHKA - as was progressively the case with Barth reception in the NGK - is an indication of how eclectic, ultra-theoretic and ultimately distorted Barth reception in the NHKA eventually became. Van Zyl simply never ventured away from his safe intellectualization of basic Barthian premises - and he never contextualized them, as Barth undoubtedly would have demanded, in the South African socio-political context either. Van Zyl filtered Barth theoretically for a church Barth himself unlikely would ever have taken any interest in. It is therefore not surprising that current vice-dean at the University of Pretoria, systematic theologian Johan Buitendag (1990:706), exactly from an ethical position, rather harshly describes the legacy of later dialectical thought in the NHKA as "bordering on monism".

Even at the dawn of critical realism, ${ }^{17}$ possibly the most important event in the philosophy of science in the second half of the $20^{\text {th }}$ century, since philosopher of science Roy Bhaskar developed aspects of the famous analysis of the historicizing engine of science by Thomas Kuhn, no one in the NHKA seemed to care about the impact it would have on conventional dialectical thought - in the 1970s in the NHKA it now simply indicated a modern, Hegelian-Barthian position, either conservatively packaged or heavily intellectualized. But critical realism posed serious challenges to this version of dialectical theology: juxtaposed with the ever-dynamic critique of modernity by so-called post-structuralists such as Foucault, Derrida and Lyotard in France and exponents such as Adorno and Habermas from the Frankfurt School in Germany, dramatically changing the face of philosophy, it was bringing conventional receptions of dialectics to its knees (Beukes 2002a:283-286; 2002b:994-1001; 2003:46-49; 2004:883-887). Some systematic theologians in the NGK already started to alter their Barth-reception in the light of the claims of critical realism, as well as the straightforward ideological-critical problems arising from the ideology of apartheid (Krüger 2003:432-435) - currently

\footnotetext{
${ }^{17}$ Critical realism in the 1970 s constituted a new philosophical approach to scientific thinking. The critical realist ontology states that something is real if it can bring about material consequences. In other words, in critical realism something is real if it has causal effects. Critical realism uses a transcendental method of argument, which most philosophies of science do not use - and the transcendental argument becomes a dialectical one in which the force is immanent critique. It argues for a kind of ontology in which the world is seen as structured, yet differentiated and ever-changing. Critical realism posed massive challenges to theology, bringing theology directly in confrontation with the philosophy of science, a confrontation taken up to international acclaim by South African (NGK) theologian, Wentzel van Huyssteen, in the late 1980s. For still the best introduction to critical realism, see Chapters 1-3 of the introduction of its major exponent, Roy Bhaskar (1997), as well as the excellent introduction of Collier (1994:1-48).
} 
Princeton-based theologian Wentzel van Huyssteen (then a systematic theologian at the University of Port Elizabeth) and Unisa systematic theologian Cornél du Toit already then at the forefront of that discourse in the NGK. But in the NHKA during the mid-1980s Barth-reception had been exactly the same it had been in 1961. One could observe that the only reason dialectical theology in the NHKA did survive or even remained relatively undamaged for so long, was, once again, because of the shadowy presence of the epistemology of the ethical orientation. Even in intellectualized Van Zylian guise, dialectical thought in the NHKA never cut itself loose from ethical epistemology: that, the distance between God and humanity notwithstanding, the classic Barthian distinction between God's truth and anthropocentric truth notwithstanding, truth can be encountered - neither the dialectical telos, any problematization of telos nor any other mundane scheme of human interests could compromise that final encounter. ${ }^{18}$ In the end, however agitating dialectical thought may be, truth is there, beyond the agitation.

One Hervormd theologian did understand that dialectical theology either had to change and adapt under the onslaught of critical realism, or face its own demise. If dialectical thought was to continue to survive in the Hervormd approach or anywhere else, it had to start engaging what was already in theology progressively (yet rather unnuanced) being called "postmodernity", seriously. New Testament scholar, A G (Andries) van Aarde, in an astonishingly productive ${ }^{19}$ career, was pivotal in the process that initiated the reconfiguration of dialectical thought in the NHKA. Since his

\footnotetext{
${ }^{18}$ T F J (Theuns) Dreyer, Moderator of the NHKA from 1998-2004, is a dialectical theologian, specializing in practical theology, who displayed in his career an astute ability to keep even the intellectualized version of dialectical theology very close to the heart and mind of the NHKA. His own analysis of the Hervormd disposition and theological temperament ([etos], Dreyer 1998, 1999) consistently relies on the strained dynamics of dialectical thought - yet consistently falls back on the ethical notion of "an encounter with the living God". Dreyer's interpretation is exemplary of the Hervormd gravitation towards ethical epistemology, even in dialectical decorum.

${ }^{19}$ By the time of his retirement in September 2005, after being appointed at UP in 1980 (and re-appointed as honorary professor from January 2008), records at the university indicated that Professor Emeritus Van Aarde held three doctorates, published 91 scholarly peerreviewed articles in accredited journals, 22 chapters in books, 38 scholarly peer-reviewed articles in co-operation with postgraduate students and research associates, 4 monographs (1 as co-author), 10 monographs (editor or co-editor of 2 collection of essays and editor of 8 books in the HTS Suppl Series) and 70 popularised scholarly articles. He has been editor of HTS for nearly 20 years. In terms of productivity, research and academic rigor, no theologian in the history of the NHKA is in close vicinity of this remarkable standard set by a remarkable dialectical theologian. Few contemporary theologians would match Van Aarde's erudite engagement with philosophy, sociology and literature studies over the span of the last three decades. Van Aarde's reputation as a classical dialectician, even from the sober angles of an archaeological point of view, is uncontested in the history and theological tradition of the NHKA: the records speak for themselves.
} 
inaugural in 1989 at Section A, Van Aarde was relentless in his pursuit of a reinterpretation of Barth, attempting to provide an alternative to both the neat conservative packaging and hyper-theorization of Barth in the NHKA (see, in a massive oeuvre, Van Aarde 1992, 1993a-d, 1994a-c, 1995a-b in particular). It is clear from the textual evidence that Van Aarde understood that even if theology in the Barthian-dialectical tradition that he inherited from Van Zyl and Engelbrecht could never be philosophy, and never should desire to become philosophy, it would have to distance itself from Barth's one-sided kerygmatic position. Postmodernity and critical realism required that dialectical theology would have to be able to speak the philosopher's language fluently - not in vain, and not with a forked tongue. ${ }^{20}$ Van Aarde typically focused on the intimate relation between dialectical theology and critical realism, which lead him to negotiate aspects of the philosophy of language, hermeneutics and critique of culture. He has been explicit about the impermanence, even volatility of language-use in theology and the inherent uncertainty of theorization in theology - however established and reliable an axiom or structure of knowledge in theology - such as a confessional, dogmatic or dogmenhistorical structure - may well be. Van Aarde's version of dialectical theology is a theological and indeed to an extent a philosophical overhaul of the inherited Barthian and, again to an extent, Brunnerian versions of dialectical theology he was confronted with. His is an open, critically "meager" mode of dialectical theology, one that appreciates the epistemological and discursive "scarcity" brought about by postmodern critique. Van Aarde does not focus on the Yes in the dialectical process, not on affirmation, not on telos, but on différence between Yes and No - in his mind the No comes into play, the re-interruption, the dubious, the starting-over with always little in hand. $\mathrm{He}$ therefore considers any attempt to reflect on God within an abstract-dogmatic vacuum, not acknowledging the necessity of ever-changing analogical language as the vehicle of his meager reflection, as "theologically suicidal" (Van Aarde 1990b:297).

Van Aarde is to dialectical theology what Loader has been to ethical theology in the NHKA: A brilliant renovator. Both of them revived layers in the Hervormd approach that were either considered to be so historicallycontingent that it might as well be dead, such as in the case of Loader, or considered to be dying, such as in the case of Van Aarde. Both critically

\footnotetext{
20 "It is no longer compulsory to compartementalize theology and philosophy ... this is a dualism which originated in the history of theology when philosophy was regarded as scholastic ... It simply is not possible any longer to sharply separate philosophy and theology ... yet they are not the same (my italics, Van Aarde 1992:960, my translation); "Philosophical engagement by dialectical theology (now) speaks for itself ... it is so obvious that it is almost trivial", (Van Aarde 1995a:17, my translation).
} 
refuted the evident final hour of the Stunde deines Niederganges of their orientations in the Hervormd approach.

Van Aarde says Yes to the No, but in Derridean fashion, it is their difference that interests him. I have opted for the No as such, an intervention or expansion made possible by Van Aarde's first move towards the No. Possibly representative of a younger generation of philosopher-theologians, I have put forward an exposition of the dialectical No, by employing the notion of "negative-dialectical" theology, a direct distillate into dialectical theology of Frankfurt philosopher Theodor Adorno's Negative Dialektik (Beukes 1996a, 2000a). This is a radicalization of Van Aarde's position, where the No or negativity becomes the kairotic yet self-relativizing moment in the dialectical process, ending it, yet immediately ending the notion of ending and therefore immediately re-initiating it, completely disregarding the notion of telos, first (or universal) principles, last (or synthetic) conclusions, radically questioning the possibility of outcome or resolve. Negative dialectics is a celebration of the dialectical process itself and not any synthetic consequence of it. It is about the discursive power of antitheses, in its essence aporetic and dubious. It is a celebration of the polemic energy and particularity in the dialectical process; about an ever-present No in reaction to any posed Yes in the dialectical movement - yet never saying Yes to that same No, not transforming the No into a newly embraced Yes. It is therefore aporetic and apologetic at the very same time - and this in my opinion is where dialectical thought in the NHKA stands today: It can linger in the difference, as in Van Aarde's disposition, or it can undermine even the difference by questioning the difference which is a form of questioning itself or a form of radical self-critique. But, whatever the case may be, we can never return to Barth or $20^{\text {th }}$ century dialectical theology without aporia, neither to its strange double-barrelled reception in the NHKA before the 1990s. ${ }^{21}$ A younger generation of Hervormd theologians has grasped this turn into the heart of contemporary philosophy, graciously

\footnotetext{
${ }^{21}$ On being dubious and aporetic: Obviously this does not imply ambivalence or unclarity, but an extreme form of inquiry. Aporia - or dubitatio - points towards a consistent insoluble impasse in an inquiry, denoting a state of being constantly perplexed, or at a loss, at the impasse. The consistent impasse in theology is God. In my frame, being a dialectical theologian equals being aporetic and dubious, inquiring and doubting the Yes to God, the Yes about God - indeed the Yes "from God Himself" (yet we know that "from God Himself" is always mediated by language and contingency and is therefore never completely from God Himself), with the tremendous implications this sense of aporia has for an interrupted understanding of, amongst others, covenant, incarnation and resurrection. Indeed, saying No to God may sound like a terrible thing, but only if that No is not immediately negated. Yes, in the end, it must be about the No - and yet, saying No even to No.
} 
accepting "Derrida's gift", in order for dialectical theology to remain theological in the afterglow of destructive postmodernity. ${ }^{22}$

Why is this - and this certainly has to be the question in the minds of Calvinists - philosophical voice from within contemporary philosophy not merely stomached, but considered intriguing in the Hervormd approach? How is it that a philosopher like myself has space to move and manoeuvre in the NHKA? Because this voice is considered to be simply one voice and one space in a multifarious realm. It is not the new School or the new Direction. In the Hervormd approach, much can be stomached, because it is so thoroughly used to more than one voice speaking at one time and more than one space being occupied at one time. In this sense, the philosopher's voice has for decades been part of the Hervormd approach and it has been given its own space to maneuver as a cross stratum over the contorted reality that is the Hervormd approach.

\section{CROSS STRATUM: THE PHILOSOPHER'S VOICE}

\subsection{Not "Gereformeerd"}

The voice of the secular philosopher within the NHKA: Its presence, its appeal, is the reason why the ethical orientation's epistemology has remained a shadowy presence in the theological attitude of the Hervormd approach for the best part of its existence, why the confessional orientation never became confessionalist and why the dialectical orientation was able to be reconfigured in the light of the critique of modernity and salvaged for dialectic discourse in $21^{\text {st }}$ century theology. This voice runs as a cross stratum through and into every layer in the Hervormd history of ideas. Our excavation is incomplete without our decyphering its presence and in-layeredness in the Hervormd approach. We will encounter one major focuspoint of orientation in the folds of this cross stratum: Kantian philosophy. Foucault's word on Kant in his introduction to the archaeological undertaking, rings true in the Hervormd approach too: Kantian critique still forms an essential part of the immediate space of our reflection. We think on this premise (Foucault 1970:11).

\footnotetext{
${ }^{22}$ For example, A J Groenewald (2004), a young Hervormd systematic theologian, has gone about the same aporetic way re-interpreting Nietzsche's critique of rationality, culture and morality, bringing it back to theology. There are numerous other examples of exciting aporetic avenues taken up by bright young Hervormd theologians studying at UP today. The aporetic voice of contemporary, modern-critical philosophy, from Nietzsche to Derrida, is to be heard in the way theology is today being understood and will be understood in the NHKA in the future.
} 
The voice of the philosopher in the NHKA is thus pertinently secular, Kantian to be more precise: it is not to be confused with the Gereformeerd understanding of philosophical intervention in theology as dangerous, profane and the immanent flipside of all that is venerable in theology. However ideatypical and rather unnuanced that description may be, Gereformeerd understanding of philosophy, often configured as "Christelike wetenskap" or "Reformatoriese filosofie" (with fundamental reference to Gereformeerd thinkers such as Stoker, Vollenhoven en Dooyeweerd, even in their own tense relation to Gereformeerd theologians proper such as Kuyper and Bavinck), has nothing to do at all with the links between philosophy and the Hervormd approach (compare Duvenage's interviews with Degenaar and Dreyer 1998a:10; 1998b:111-114). Gereformeerd theology, in the event of an altercation with secular philosophy, immediately searches for an Archimedes Point ${ }^{23}$ that one element or moment in discourse which could be isolated from critical rationality, which, as the secular philosopher will always say, would have to be out of this world. Therefore Gereformeerd theology necessitates Gereformeerd philosophy, even if it dislikes even that kind of philosophy, which at least would stand by its side, out of this world. But this certainly is not the kind of escapist, conformist philosophy the excavated top layer in our investigation, in particular, reveals. Rather the dialectic layer reveals the Brunnerian apologetic attempt to come to grips with secular philosophy, without devising it into a tool for Calvinist self-preservation. The Brunnerian presence in the NHKA, nourished by Kant and Schleiermacher, a presence which exerted an enormous influence on the Hervormd approach for nearly three decades, from the early 1930 s up to the early 1960 s, as indicated above, simply embraced secular philosophical discourse (Dreyer 1989:336339; Duvenage 1998b:110). Krüger (2003:423) is therefore correct in a recent analysis where he concludes in somewhat of an understatement that "throughout the century, the typical NHKA approach was more philosophically guided, less (quasi-)directly based on scriptural data", than the GKSA and the NGK. Not only was the Hervormd approach more philosophically guided than any other local theological approach, it was and is inherently philosophically guided, exactly because of the ever present claims of ethical epistemology, always running in the background, as well as the Brunnerian apologetic presence in the initial dogmatic and religio-philosophical labour in the NHKA.

\footnotetext{
${ }^{23}$ L F Schulze, a well respected Gereformeerd theologian, in an introduction to the claims of Gereformeerd theology, states in an exemplary Gereformeerd view on philosophy: "The cultural disintegration of the West is cemented in postmodernism with its pluralism and radical relativism ... the only escape from this gridlock is an Archimedes Point outside this world" (Schulze, 1995, Inleiding in die grondslag van die gereformeerde teologie, In die Skriflig 29(1\&2), 5-28; this quote p19, my translation).
} 
Krüger (2003:423) is also correct in his depiction of Hervormd theological training at UP as being characterized by intense philosophical input, with substantial and compulsory education in philosophy in the undergraduate programme (for many years, sadly not anymore, it was compulsory for Hervormd students to major in philosophy), resulting not only in numerous Hervormd theologians with magister degrees and doctorates in philosophy, but in Hervormd theologians and ministers who were extremely competent in philosophical discourse within their daily theological enterprises, especially so in the pulpit (Dreyer 1989:335; see Beukes 1999:159-160). For the best part of both parties' existence, the Department of Philosophy at the University of Pretoria and Section A were closely knit, very much a unit in their attempt to prepare ministers for the NHKA that were not only theologically, but philosophically competent (Dreyer PS 1989:347; see Beukes 2000b:71-73). The intention was not to breed philosophers in the pulpit, but to present the church with educated ministers in the classic sense, women and men with Bildung, who could hold their own in any intellectual environment. Philosophy plays an enormous role in providing a person with that kind of intellectual elegance and grace.

The Hervormd approach therefore did not simply endure with pastoral patience the presence of the philosopher in its midst: It relished in and cherished the philosopher's voice and is up to this day heavily indebted with regards to its stylish, "never simplistic-fundamentalist" (Krüger 2003:423) theological orientations to the input of philosophy. This notion is being reflected by the amount of hardcore philosophical contributions in both the accredited journal associated with the NHKA, HTS and Die Hervormer, the NHKA's fortnightly newspaper, over the past decades. One is actually astonished to observe the amount of philosophical articles published in HTS over the past five decades, with an intensification of this tendency during the past two decades under the editorship of $A G$ van Aarde.

\subsection{Rautenbach, Dreyer, Oberholzer: Bildung}

Three philosophers at the Department of Philosophy at the University of Pretoria, who had strong ties to the NHKA and Section A as such, were particularly prominent in their utilization of the initial Brunnerian apologetic space, employing philosophy in the heart and mind of the Hervormd approach: C H Rautenbach, P S Dreyer en C K Oberholzer, Rautenbach and Dreyer being exemplary of the rather typical Hervormd kind of predikantphilosophers Krüger (2003:423) refers to, Oberholzer being an ouderling (elder) of the NHKA. 
A collection of $\mathrm{C} \mathrm{H}$ Rautenbach's ${ }^{24}$ extended legacy was edited and published by his younger colleague P S Dreyer in 1975, titled $C H$ Rautenbach: Versamelde Geskrifte. Rautenbach's contributions in this collection present us a philosopher who was extremely interested in the relationship between philosophy, didactics and theology, especially with regards to their interplay and as far as Rautenbach was concerned, their natural similarity. These contributions nevertheless point towards a philosopher who was endeared to the NHKA on more than an intellectual level: With his own philosophical input, he had the well-being of the NHKA in mind, even going as far as to describe his association with the theology in the NHKA as a prerequisite for his philosophical labour, which is quite remarkable (see Rautenbach 1975:ii).

Any theology which refuses to confront the philosophical critiques of the age that theology contextualizes itself in, strikes Rautenbach as incomplete, to say the least - even as futile, to say it a bit harsher. Rautenbach typically focuses on the didactic, formative qualitities philosophy brings to theology. Philosophy establishes Bildung in the heart of theology, which, untranslatable as the word is, refers to a critical framework of reference, a discursive literacy, an erudition and a sense of the vastness of the Western canon, those oldest of the sources of the Self, in which theology must always re-establish itself anew, those cultural sources theology always has to engage anew (see Rautenbach 1975:61). Philosophy confronts the theological sense of time with theology's own temporality. Philosophy thus emphasizes modesty in theology. A modest theology, for Rautenbach, is a beautiful theology, one that is beginning to appreciate its Bildung.

It is clear, as P S Dreyer (1989:338) indicates, that the didactical and institutional element of philosophical input in the training of Hervormd theologians was initiated by Rautenbach himself, initially as chair of the Department of Philosophy at the University of Pretoria in the 1940s and eventually as Rector of the university from 1948 to 1970 . Rautenbach had the means and the capability to integrate philosophy and theology in the Hervormd approach on an institutional and administrative level. He did so with austerity. ${ }^{25}$

\footnotetext{
${ }^{24} \mathrm{C}$ H Rautenbach (1903-1988) initially was a part-time lecturer from 1924 to 1926 and from 1939 to 1948 a full-time lecturer in philosophy at UP. Up to 1939 Rautenbach was a full-time dominee (minister) in the NHKA. In 1948 he was appointed Rector of UP, a post he by all indications served with distinction up to his emeritate in 1970. For a sympathetic biography, see Van Deventer H T 1987, Casper Hendrik Rautenbach: "Singewing aan dink al hoe meer in verband met doen", HTS 43, 2-12.

${ }^{25} \mathrm{Had}$ our archaeology allowed us to expand on the intellectual influence Rautenbach had on the NHKA and his spiritual legacy in the NHKA, we would have been able to give an extensive account of exactly that: Rautenbach, a philosopher by trade and by heart, was a pivotal intellectual figure in the NHKA for the best part of the 20th century. That says a lot about the historical place of the philosopher within the NHKA.
} 
Rautenbach's philosophical style could be depicted as phenomenological and experience-orientated. He often refers to philosophy as the "science of experiences" and accentuates the rational and logical processing of experience data (see Rautenbach 1975:97). Philosophy, in Rautenbach's mind itself a science, thus works with the capabilities and restrictions of rationality. Philosophy should be able to explain these restrictions - that, to Rautenbach, is an imperative. This orientation places Rautenbach squarely in the Kantian tradition, in the sense that philosophy is being considered an act where the initiative for the acquisition of knowledge is established in the knowing and acting subject (Rautenbach 1975:95). In an article, entitled "Wetenskap en Geloof" (Science and Faith, Rautenbach 1975:95 ev) this Kantian position is worked out extensively, especially with regards to the relationship between philosophy and theology, which Rautenbach considers as intimate. Theology needs to be challenged by the apparatus of critical rationality, it has to be forced to denote and signify the nature of its own unique rationality - when theology appears before the judge of reason, there has to be a verdict on the kind of rationality theology utilizes. And if it is weak rationality, or quasi-rationality, or irrationality, the verdict will lay it bare in the folds of history (Rautenbach 1975:97, 99; Dreyer 1989:335). Philosophy liberates theology from lingering in ungrounded and speculative labyrinths, consistently bringing theology back to its roots in logics and hermeneutics (Rautenbach 1975:101). Both theology and philosophy are restricted enterprises: As Kant argued, rationality is restricted and science is therefore restricted. Theology as a science has to answer in what sense the rationalities it employs, is restricted; in what sense theology is a restricted domain. Only with this self-critical attitude theology can hope to say something coherent about God and human destiny (lewenslot, Rautenbach 1975:101). By introducing the notion of self-critical awareness in theology, Rautenbach put forward a blueprint for the relationship between theology and philosophy that has been honoured in the Hervormd approach up to this day. His Kantian intuitions resonated well with the established apologetic space of Brunner's dialectical theology and the open-ended epistemology of the ethical orientation in the Hervormd approach.

It was exactly those Kantian intuitions that were worked out extensively by his successor at the Department of Philosophy at the University of Pretoria, P S Dreyer. ${ }^{26}$ Dreyer was by all accounts one of the most highly rated Kant

\footnotetext{
${ }^{26}$ P S Dreyer (1921-1999) studied theology and philosophy at the Universities of Pretoria and Groningen from 1938 to 1950 and obtained doctorates in both disciplines. Dreyer held a professorate in philosophy from 1952 up to his emeritate in 1986. He was head of the Department of Philosophy at UP from 1970 to 1986. Dreyer, the quintessential Hervormd predikant-philosopher, never allowed his status as minister of the NHKA to be compromised in any way, although he was forced by church ordinances to serve on the General Commission of the NHKA (for many years) as an elder.
} 
scholars of his day, at least locally: his extensive oeuvre bears witness to that (Beukes 2000b:75). His elaborate introductions in Early Greek and Classic philosophy, the Philosophy of History as well as Philosophical Ethics, apart from his numerous publications on Kant, the last a translation and commentary on Kant's Grundlegung zur Metaphysik der Sitten, published years after his emeritate (Dreyer 1997), provide us with an archive of high value (for an elaboration, see Antonites 1986:434).

Dreyer's position on the relationship between theology and philosophy differed in no way from that of his predecessor. Theology had to engage in philosophical discourse. Yet this is a tense and delicate engagement. Dreyer often gave an indication of an understanding of philosophy as a cruel, vicious and uncompromised enterprise, which he wanted to protect the church and theology from (e g Die Hervormer 15 Mei 1995:5). Dreyer was for that reason very selective in the way he himself engaged in this relationship. To him, theology should not in any way be subordinated to philosophy. Dreyer had no desire to educate philosophers for the church; rather, like Rautenbach, over a period of more than three decades, he worked towards the education of students who were philosophically erudite in their engagement with theology and the church, skilled in the discursive practices of the society they found themselves in. They had to be sure that they wanted to speak the "language of the church", and not "merely the language of philosophy" (Die Hervormer 15 Mei 1995:5). Yet in postmodernity, as G M J van Wyk has indicated (Van Wyk 1994a-b; see Beukes 1999:150), it has become impossible to keep these languages in isolation. Actually, they will progressively become one and the same language (Beukes 1999:158; see Van Wyk 1994a:5).

In his serious philosophical labour Dreyer engaged fully and critically with theology, especially along Kantian and Kierkegaardian ${ }^{27}$ lines (see Duvenage 1998b:107; Van Aarde 1997:[1]). Dreyer argued - and he gave an excellent summary of his Kantian position which was formed over several decades in a post-emeritate publication in Dreyer (1990) - that philosophy and theology were in juxtaposed relation after Kant, because Kant succeeded in integrating the claims of practical and theoretical reason. They work with different concepts, points of departure and methods, but practical reason - to believe - and theoretical reason - to know - can be harmonized, as long as both respect the parameters of their own claims (Dreyer 1990:583-586). As a consequence of the restriction of theoretical reason, the possibility of faith standing its ground in the face of theoretical reason, becomes distinct (Dreyer 1990:584). This is why theology and philosophy belong together, yet in

\footnotetext{
${ }^{27}$ For an analysis of and commentary on Dreyer's Kant reception, as well as a commentary on his reading of Kierkegaard, see Beukes (2000c:33-38).
} 
different compartments. They can and should be distinguished, but neither should be subordinated. For Dreyer it would be unthinkable to have to invent or import a kind of philosophy that would fit theology's claims, as in Gereformeerd practice. The philosopher's voice should be heard as it is, though that voice has its own particularity, as has the voice of the theologian.

But what is important for our archaeology is that Kantian philosophy, via the parameter model of theoretical and practical reason, presents a structure of discontinuity which corresponds with the basic tenets of the ethical and dialectical orientations, presenting God as intrinsically unknowable, drawing a clear line which humans existing in the human condition can not cross through their own initiative - only God can make Himself knowable and practical reason alone has the ability to handle that kind of presentation or revelation (Dreyer 1990:590). Kant assists theology to recognize its restrictions, yet embrace the validity of its claim to faith.

Dreyer's somewhat older contemporary, C K Oberholzer, ${ }^{28}$ one of the first formal exponents of phenomenology and existentialism in South Africa, was a more daring, challenging and complex philosopher than both Rautenbach and Dreyer (e g Oberholzer 1975:50-55). His style was much more confrontational, in the sense that he challenged students of theology to give answers to the philosophical problems arising from both Protestant dogmatics and modern culture itself. Less of an outspoken Kantian and more of an existentialist, Oberholzer made use of the basic tenets of existentialism to expose for students the vulnerability of the individual in modern society, yet always bringing this vulnerability back to the task of theology: Theology, if it took existentialism seriously, had to engage in a critique of culture. Theology should be confrontational and polemic towards culture - and to engage in debate with society regarding the fragile disposition of the single, individual believer (enkelgelowige), theology had to be able to speak the language of philosophy fluently. Oberholzer demanded students of theology to take critical leave of society, to look at the world they would theologize in, with a distant, critical eye. They need not conform to that world. Rather, they need to engage that world, theologically yes, but never in the absence of the philosopher's voice. The only alternative is moralism, which to Oberholzer was an abomination. Although he was less involved in structural and institutional

\footnotetext{
${ }^{28} \mathrm{C}$ K Oberholzer (1904-1983) was professor of philosophy from 1948 to 1969 at UP. He headed the department from 1952 to 1969 and was an elder in the NHKA. A former student, who became a celebrated pedagogician, W A Landman, declares: "Without fear of contradiction it is stated that (Oberholzer) is the greatest authority and exponent in South Africa of phenomenology, philosophical anthropology, child anthropology and phenomenological axiology. Also his existential-phenomenological thinking has exerted and continues to exert a fundamental influence" (Landman 1979:29; see http://www.landmanwa.co.za/onlandmoo.htm).
} 
matters concerning the proceedings of the church than Rautenbach and Dreyer, Oberholzer claimed that the validity of the philosopher's voice within the Hervormd fellowship was indisputable. To him, it was a matter of the intellectual and cultural-critical integrity of the theologian and minister that $\mathrm{s} / \mathrm{he}$ took philosophical discourse seriously (Oberholzer 1975:75-81). An unphilosophical predikant was to him a crudity.

These three philosophers were succeeded by other predikantphilosophers in the Department of Philosophy at the University of Pretoria who in the Hervormd approach continued the tense yet productive interplay between theology and philosophy, though they were less institutionally involved in church matters than Rautenbach and Dreyer, notably A J Antonites, J D Gericke (emeritus) and M J Schoeman, the latter not a minister or theologian, yet a prominent member of the NHKA and over the course of the past three decades intensely involved in the philosophical training of theology students of the NHKA. Currently Ernst Wolff, senior lecturer at the department and proponent in the NHKA, has a lot to offer the Hervormd approach by way of his exciting culture-critical and hermeneutical engagement with theology (see Wolff 2000, 2006). Numerous ministers in the NHKA over the course of the past decades obtained magister degrees and doctorates from that department and other universities, notably the University of Johannesburg (formerly Rand Afrikaans University), where J J Snyman, a celebrated Adorno scholar, over the past decade supervised dissertations of two Hervormd theologians, G M J van Wyk and the author.

The philosopher's voice in the Hervormd approach is still alive, but only just: Much more should be done to encourage undergraduates to major in philosophy - fully engaging in postgraduate studies in philosophy and upholding the critical notion of the philosopher's voice in the Hervormd approach. The curatorium of the NHKA would make no mistake in reinstating the former arrangement of undergraduates majoring in philosophy before enrolling in the MDiv (formerly BD) course. The risk of losing the characteristic philosophical erudition amongst Hervormd theologians and ministers is unfortunately becoming a reality, precisely because the old Hervormd rule of mandatory majoring in philosophy in the undergraduate programme, has fallen away. Given the vastness and beauty of the Kantian legacy they inherit, Hervormd theologians and ministers indeed could be expected to re-engage that legacy. Our archaeology has on each and every layer put this requirement forward as an imperative. Even the confessional stratum, if it really is as self-critical as it claims it is, is deeply dependent on this legacy. In the face of the ongoing critique of modernity and its devastating effects on the theological realm, the possibility of the disintegration of the philosopher's 
voice in the Hervormd approach is to this archaeologist very hard to come to grips with. This voice is as integral a part of the Hervormd approach as the voice of the confessional theologian, the ethicist or the dialectician.

An archaeologist appreciates contours. Our investigation into the Hervormd history of ideas revealed a contorted reality, three layers of theological orientation, as well as a cross layer regarding an intimate orientation towards philosophy. Digging into this intellectual history did not reveal a monolithic enterprise or a school theology or a dominant strand of reflection on God and the world. Our excavation revealed seemingly disassociated bodies of theological precedents which co-existed for at least six decades, layered into each other, interrupting each other, never giving in to the pressure of capitulating to the appeal for one position or layer of argument, never leading to a school of thought or one single orientation.

The beauty of the Hervormd approach has to be this symphonic quality and tense contortedness. It is not exclusively confessional, or ethical, or dialectical, or philosophical - tensely curved and painfully arched, it is all of these. Our excavation re-awakened a deep respect in the author's mind for the inexplicit nature of this multifarious kind of theology. From the layers laid bare, I now call for an ongoing estimation of the diversity of voices within the Hervormd approach. If the Hervormd approach is able to withstand external (particularly ecumenical) and internal (particularly confessionalist) pressure to integrate these different layers into a monolithic enterprise of knowledge about God and the world, if it is able to remain "Hervormd" in that regard, the Hervormd approach will do justice to the voices that have carried it into the $21^{\text {st }}$ century. The Hervormd approach really does not need to be more than the voices that carry it. But these voices need to become more and more eloquent, they need to carry new meanings into a new world. Future archaeologists and future excavations will have to indicate what these voices have carried into new times.

\section{Works consulted}

Antonites, A J 1986. P S Dreyer: Bakens op die pad van die wetenskap. HTS 42, 434-461.

Bhaskar, R 1997. A realist theory of science. London: Verso.

Beukes, J 1996a. Anderbereddering: Met Adorno by die hartslag van die postmoderne intellek. HTS 52, 68-87.

Beukes, J 1996b. Michel Foucault en die historisering van Anderswees. HTS 52, 233-251.

Beukes, J 1999. Filosofie en teologie in die laat twintigste eeu: 'n Redekritiese waardering, in Van Wyk, D J C (ed), 20ste Eeu Hervormde Teologie, 142161. Pretoria: Sentik. 
Beukes, J 2000a. Die redekritiese aansprake van 'n negatief-dialektiese teologie. HTS 56, 245-285.

Beukes, J 2000b. C H Rautenbach, C K Oberholzer en P S Dreyer: Hulle nalatenskap en die pad vorentoe. HTS 56, 70-105.

Beukes, J 2000c. 'n Postmoderne redekritiek vir kerk en teologie. PhD Dissertation, Faculty of Theology, University of Pretoria.

Beukes, J 2002a. Ars erotica en die detrivialisering van die seksuele diskoers: 'n Aantekening by die seksualiteitsanalise van Michel Foucault. HTS 58, 283298.

Beukes, J 2002b. Vanaf laat-strukturalisme na post-strukturalisme: 'n Kontekstualisering van Jean-François Lyotard se Discours, Figure. HTS 58, 994-1010.

Beukes, J 2003. Kultuurkritiek en die Hervormde benadering tot teologiebeoefening: 'n Gestaltegewing en Uitdaging. HTS 59, 31-46.

Beukes, J 2004. Teenswoordige geskiedenis: Michel Foucault in gesprek met die teologie. HTS 60, 883-899.

Boshoff, P B 1992. 'n Kenmerkend Hervormde teologie. Die Hervormer 1 Nov 1992, p 4.

Breytenbach, A P B 1992. Egge Simon Mulder, hoogleraar 1956-1970. HTS 48, $101-$ 112.

Breytenbach, A P B 1999. Ontwikkelings en verskuiwings in ons teologie, in Van Wyk, D J C (ed), 20ste Eeu Hervormde Teologie, 171-182. Pretoria: Sentik.

Buitendag, J 1990. Die paradigmas van "Kerk en wêreld 2000". HTS 46, 690-707.

Buitendag, J 1992. Die etos van die Nederduitsch Hervormde Kerk: Memorandum in die Handelinge van die TKK. Pretoria: Archives of the Nederduitsch Hervormde Kerk.

Buitendag, J 2006a. New wine in new skins and the conservation of both: Rethinking the identity of the Hervormde Church at the beginning of the $21^{\text {st }}$ century. HTS 62, 343-362.

Buitendag, J 2006b. Coming in from outside: A crucial event in the history of ecumenism of the Nederduitsch Hervormde Church. HTS 62, 787-817.

Collier, A 1994. Critical realism: An introduction to Roy Bhaskar's philosophy. London: Verso.

Dreyer, P S 1989. Die wysgerige agtergrond van die Hervormde teologiese opleiding aan die Universiteit van Pretoria. HTS 45, 335-349.

Dreyer, P S 1990. Die filosofie van Immanuel Kant en Protestant-teologiese denkstrukture. HTS 46, 582-595.

Dreyer, P S 1997. Immanuel Kant: Fundering vir die metafisika van die sedelikheid. Pretoria: Promedia. (HTS Suppl 8.)

Dreyer, T F J 1998. Spiritualiteit, identiteit en die etos van die Nederduitsch Hervormde Kerk. HTS 54, 289-314.

Dreyer, T F J 1999. Hervormde etos en die roep om spiritualiteit, in Van Wyk, D J C (ed), 20ste Eeu Hervormde Teologie, 255-269. Pretoria: Sentik.

Duvenage, P 1998a. Om die wêreld te ontdek. (Interview with J Degenaar.) Fragmente 1, 7-23.

Duvenage, P 1998b. Filosofie, teologie en die geskiedenis. (Interview with P S Dreyer.) Fragmente 2, 102-119. 
Engelbrecht, B J 1949. Die tydstruktuur in die gedagtekompleks Hegel, Kierkegaard, Barth. DTh Dissertation, Faculty of Theology, Rijksuniversiteit Groningen.

Foucault, M 1970. The order of things: An archaeology of the human sciences, tr by Sheridan Smith, A M. New York: Vintage.

Foucault, M 1972. The archaeology of knowledge, tr by Sheridan Smith, A M. London: Tavistock.

Foucault, M 1973. The birth of the clinic: An archaeology of medical perception, tr by Sheridan Smith, A M. New York: Pantheon.

Groenewald, A J 2004. Nietzsche's impulse towards the development of a concept of God that transcends modern atheism and theism: A philosophical theological study. DD Dissertation, Faculty of Theology, University of Pretoria.

Koekemoer, J H 1994. Die idioom van die Nederduitsch Hervormde Kerk - 'n Teologiese vraag. HTS 50, 14-26.

Krüger, J S 2003. Sweeping whirlwinds: A study of religious change: Reformed religion and civil religion in the city of Pretoria (-Tshwane) (1855-2000). Pretoria: UNISA.

Landman, W A 1979. C K Oberholzer as essensie-denker, in Smit, A J (ed), Die agein perenne: Studies in die pedagogiek en die wysbegeerte, 29-40. Pretoria: Van Schaik.

Loader, J A 1984. Die etiese Ou-Testamentici in Nederland tussen 1870 en 1914. DTh Dissertation, Faculty of Theology, University of South Africa.

Loader, J A 1987. "Tertium datur" - oor die etiese waarheidsbegrip. HTS 43, 47-57.

Loader, J A 1987. Ontstaan en eerste periode van die Hervormde teologiese opleiding aan die Universiteit van Pretoria. HTS 45, 412-437.

Loader, J A 1990. Bybelwetenskappe in die Nederduitsch Hervormde Kerk van Afrika 1880-1990, in Verslag: Wetenskapsteorie en vakmetodologie in Bybelwetenskaplike navorsing in Suid-Afrika: 'n Wetenskapsteoretiese en sosiaal-historiese studie, Vol 3, Sec B, Parts 2-4, 1-109.

Loader, J A 1993. Ek staan by Kerk se belydenis. Die Hervormer 86(6), p 3 \& 6.

Loader, J A 1996. 'n Hervormde tradisie as heelmiddel. HTS 52, 566-589.

Oberholzer, C K 1975. Moderne persoonsvisies. HTS 31, 45-81.

Oberholzer, J P 1993. Die teologiese eie-aardigheid van die Nederduitsch Hervormde Kerk: Vrae en nuanses. HTS 49, 870-886.

Oberholzer, J P 1994. Tendense in teologiese opleiding: Die pad vorentoe. HTS 50, 27-38.

Pont, A D 1994. Historiese perspektiewe op die kerklik-teologiese opleiding van die Nederduitsch Hervormde Kerk aan die Universiteit van Pretoria. HTS 50, 95110.

Rautenbach, C H 1975. C H Rautenbach: Versamelde geskrifte. Dreyer, P S (ed). Pretoria: HAUM.

Van Aarde, A G 1992. Hoe praat ons oor/van God? Teologiese idiome van gister en van vandag. HTS 48, 957-976.

Van Aarde, A G 1995a. Kerk en teologie op pad na die derde millennium: 'n Paradigmatiese verskuiwing van middelmatige aard. HTS 51, 13-38.

Van Aarde, A G 1995b. Kerk en teologie op pad na die derde millennium: Gedagtes oor die kontekstualisering van die dialektiese teologie in 'n plurale samelewing. HTS 51, 39-64. 
Van Aarde, A G 1999a. Wat is waarheid? 'n Teologiese antwoord van 'n Bybelwetenskaplike, in Van Wyk, D J C (red), 20ste Eeu Hervormde Teologie, 1127. Pretoria: Sentik.

Van Aarde, A G 1999b. Dekonstruksie van dogma: 'n Eietydse ondersoek na die spore van die leer van die twee nature van Jesus. HTS 55, 437-470.

Van Eck, E 1999. Nuwe-Testamentiese eksegese en teologie, in Van Wyk, D J C (ed), 20ste eeu Hervormde Teologie, 40-48. Pretoria: Sentik.

Van Eck, E 2006. The Word is life: African theology as Biblical and contextual theology. HTS 62, 679-701.

Van Staden, P 1994. Mag "slegs blankes!" hier aanbid? HTS 50, 713-729.

Van Wyk, D J C (sr) 1990. P J Hoedemaker: "Wat ék bedoel, is die behoud van die kerk". HTS 46, 497-512.

Van Wyk, D J C (sr) 1998. Wortels en agtergronde van Hervormde teologie en kerkwees in Suid-Afrika. HTS 54, 245-263.

Van Wyk, D J C (sr) 1999a. Die ander opsie: Kohlbrugge - Hoedemaker - Barth. HTS 55, 120-151.

Van Wyk, D J C (sr) 1999b. Hervormde Kerk, teologie en lewe: Aksente en nuanses, in Van Wyk, D J C (ed), 20ste Eeu Hervormde Teologie, 183-198. Pretoria: Sentik.

Van Wyk, G M J 1994a. In die postmoderne tyd moet die teologie 'n filosofiese teologie wees. Die Hervormer 15 Maart 1994, p 5.

Van Wyk, G M J 1994b. Oor die grens(e) tussen teologie en filosofie. Die Hervormer 1 April 1994, p 5.

Van Wyk, I W C 1994a. Nog steeds geslote eredienste? Deel 1. HTS 50, 755-779.

Van Wyk, I W C 1994b. Nog steeds geslote eredienste? Deel 2. HTS 50, 1070-1093.

Van Wyk, I W C 1997. Moet die Afrikaanse kerke skuld bely oor apartheid? Wat leer ons uit die Duitsers se worsteling met skuld? HTS 53, 1399-1436.

Van Wyk, J H 2000. Quid est Veritas? Augustinus oor waarheid en leuen - en latere ontwikkelings. HTS 56, 456-591.

Van Zyl, F J 1958. Die Analogia Entis: 'n Godsdiensfilosofiese ondersoek. DD Dissertation, Faculty of Theology (Sec A), University of Pretoria.

Van Zyl, F J 1993. Dialektiese teologie. Die Hervormer 1 Oktober 1993, p 5 \& 6.

Van Zyl, F J 1994. Dit gaan om redding, nie om hulp nie. Die Hervormer 1 Julie 1994, p 5.

Van Zyl, F J 1999a. Kerklike verkondiging in dialekties-teologiese perspektief. HTS $55,22-47$.

Van Zyl, FJ 1999b. Aktualiteit en neerslag van Karl Barth se versoeningsleer in ons teologie, in Van Wyk, D J C (ed), 20ste Eeu Hervormde Teologie, 406-419. Pretoria: Sentik.

Wolff, E 2000. Wanneer klop jy jou pyp op jou velskoen uit?: Oor stories en kultuurkritiek. HTS 56, 1200-1222.

Wolff, E 2006. Anatomie van 'n ideologiese teologie: Die Hervormde Kerk se steun aan die Apartheid ideologie. Historia 51(1), 141-162. 